\title{
EFFECT OF SPRAYING HYDROGEN CYNAMIDE, GARLIC OIL, OLIVE OIL AND JASMINE OIL ON EARLINESS OF BUDBURST, YIELD AND FRUIT QUALITY OF FIG (SULTANI cv.)
}

\author{
(Received: 7. 5. 2018) \\ By \\ Shereen A. Shaheen, A. S. El-Soda and T.K. El-Bolok \\ Department of Olive and Semi-arid Zone Fruits, Horticulture Research Institute, \\ Agriculture Research Center, Giza, Egypt.
}

\begin{abstract}
The present investigation was conducted during the two seasons , 2013 and 2014 to assess the effect of foliar application of garlic oil (3\%), olive oil (3\%), jasmine oil $(0.3 \%)$ as a natural oils and hydrogen cyanamide at $1.5 \%$ (Hydrogen cynamide), alone or in combinations, on the percentage and date of buds emergence, vegetative growth, fruit quality and yield of Sultani fig cultivar grown under Sohag Governorate conditions. All sprayed treatments significantly improved vegetative growth, fruit quality and yield. The combination of olive oil and hydrogen cyanamide gave the highest values of the studied traits, earliness of the buds emergence and its improved percentage, enhanced vegetative growth and the number of fruits/tree. It also led to advancement of harvesting date, reduced immature fruit $\%$, promoting yield and fruit quality, that led to achieve high profit compared to other treatments and the control (untreated).
\end{abstract}

Key words: fig, olive oil, garlic oil, jasmine oil, hydrogen cynamide.

\section{INTRODUCTION}

Fig is one of the cultivated deciduous fruits. They were first selected by the Arabs in south west Asia and transmitted to Syria, Mediterranean region, Greece, Italy and Spain (Moshe 2008). The Mediterranean basin climate with hot dry summer and cool wet winter predominates in the fig trees region of origin, and characterized as a temperate subtype climate. Fig fruit is a highly perishable climacteric fruit that has been referred to as the oldest species of the fruit trees cultivated for over 5000 years ago (Wang et al., 2003 and Oukabi and Mekaoui, 2012). Figs have been grown in Egypt since ancient times and their fruits are of the major fruits for local consumption. Egypt is considered the second producing country in the world (F.A.O. 2011).

The trees grow successfully from Mediterranean coast to Aswan. The Northern coast of Egypt from Alexandria to the west in Marsa-Matrouh, is considered the most dense area of fig production. The Sultani fig is the local standard variety grown under the climatic conditions of Egypt and is consumed fresh. One of the main problems that faces fig growers is the late maturation of fruits in some areas and the decrease of the trees profitability. This may be due to the effect of climatic changes on fruits which remain immature on the trees till the end of the season (El-Bolok 2006 and Souza et al., 2009). Dormancy is the phase of development that occurs annually in deciduous fruit trees (Saure, 1985). Release from dormancy requires a chilling period during winter followed by a temperature rise in spring (Fuchigami et al., 1982). Under the inadequacy of accumulated cold hours, the use of chemical products that causes dormancy braking and that act as a sprouting inducers (Settimi et al., 2005). Hydrogen cynamid is used in the case of lack of sufficient cold hours in the winter, and when it is needed to standardize and anticipate sprouting. This leads to early harvest, which is related to the effects on respiratory system of cells and the interference with some enzyme activity that control the plant's rest, such as the catalase activity. Although the hydrogen cynamide is the 
most effective compound in the dormancy breaking agents, the necessity of alternatives is vital (El-Sabrout, 1998 and Mcartney \& Walker 2004). Recently researchers have shown an interest in the application of non-toxic alternatives instead of synthetic chemicals as dormancy breaking agents of fruit trees, to improve plant growth. Jasmine oil is one of the essential oils that may have a role as protective substances against stress (Zaghloul et al., 2011). Essential oils may slow some vital processes, while enhance juvenility, lowering consumption of sugars by hindering ethylene action and retarding the quick senescence of plant organs and in turn utilization of sugars (Feng et al., 2003).

Garlic oil is a natural product that works as an alternative for dormancy breaking agents of temperate climate fruit trees, mainly for alternative production systems, which restricts the use of agrochemicals (Omri, 2006 and Segantini et al., 2011). The hypothesis of using this product is based on the presence of sulfur compounds such as di allyl di sulfide, which play the main role as dormancy-breaking agent of different species of deciduous plants (Hartmann et al., 2000; Ahmed et al., 2009 and Pinto et al., 2014).

Olive oil is one of the natural compounds with the tendency to be used as a dormancy breaking agent to accelerate the maturity of fruits. It has been known since the $3^{\text {rd }}$ century $\mathrm{BC}$ that a drop of olive oil applied to the ostiole (a process termed as Oleification) of the fig fruit stimulates growth and leads to uniform ripening of fruits (Owino et al., 2006). It was observed that refined olive oil was more effective in accelerating maturation of the fig fruit as compared to vegetable oils. Fatty acids especially linolenic acid was more effective in hastening maturation of figs by inducing rapid production of ethylene (Hirai et al., 1996).

In the present study, natural oil products (garlic oil, olive oil and jasmine oil) were sprayed as alternatives for comparing with the synthetic chemical hydrogen cynamide, and synthetic chemical hydrogen cynamide, and studying their effect on reducing harvesting period and immature fruit percentage, as well as improvement of yield and fruit quality of Sultani fig cultivar grown under Sohag Governorate conditions.

\section{MATERIALS AND METHODS}

This study was carried out during two seasons (2013 and 2014) at the Horticultural Research Station Orchard in Shandaweel, Sohag Governorate, Egypt, on fig Sultani cultivar. The experimental trees were about twelve year old propagated by leafy cuttings and planted at $4 * 4$ $\mathrm{m}$. Trees were free from pathogens and physiological disorders and received the common culture practices, pest control and fertilization program recommended by the Ministry of Agriculture, Egypt Soil texture of the experimental orchards was silt clay loam and irrigation was by the flooding irrigation system. Trees were pruned (light winter pruning ) during the first week of January in both seasons The trees were sprayed after pruning at the second week of January with Hydrogen Cynamide, garlic oil, olive oil and jasmine oil (alone and in combinations). Foliar sprays were applied using a hand pressure sprayer. Triton B $(0.2 \%)$ the emulsifier was added as a surfactant for each treatment. Seventy-two uniform trees were chosen. The experimental design used was a complete randomized block design, where each three fig trees acted as a replicate and each three replicates were treated by one of the following spraying treatments:

1- Tap water (control).

2- $1.5 \%$ hydrogen cynamide (H.C.).

3- $3.0 \%$ garlic oil.

4- $3.0 \%$ olive oil.

5- $0.3 \%$ jasmine oil.

6- $1.5 \%$ hydrogen cynamide $+3 \%$ garlic oil.

7- $1.5 \%$ hydrogen cynamide $+3 \%$ olive oil.

8- $1.5 \%$ hydrogen cynamide $+0.3 \%$ jasmine oil.

Chemical analysis of garlic, olive and jasmine oils were carried out according to the methods of Lanzotti (2006), Ewa et al. (2015) and Kittikorn \& Kanlayanarat (2004), respectively, as shown in Tables (1,2 and 3). 
Table (1): Chemical analysis of garlic oil.

\begin{tabular}{|l|c|}
\hline \multicolumn{1}{|c|}{ Components } & Values \\
\hline 2-Vinyl-4H-1,3-dithiin (\%) & 2.65 \\
\hline 3,3-Thiobis-1-Propene (\%) & 4.12 \\
\hline Methyl-propenyl- disulfide (\%) & 0.43 \\
\hline allicin (\%) & 23.53 \\
\hline Diallyl disulfide (\%) & 21.98 \\
\hline Di-2-propenyl tri sulfide (\%) & 6.31 \\
\hline Dimethyl-tri sulfide (\%) & 17.43 \\
\hline Eugenol (\%) & 6.76 \\
\hline Diallyl tetra sulphide (\%) & 2.65 \\
\hline Diallyl penta sulfide (\%) & 0.32 \\
\hline Methyl allylpenta sulfide (\%) & 0.13 \\
\hline B-caryophyilene (\%) & 3.93 \\
\hline Methyl allylhexa sulfide (\%) & 5.87 \\
\hline Protin (\%) & 3.2 \\
\hline Fat (\%) & 0.1 \\
\hline Carbohydrates (\%) & 13.8 \\
\hline Fiber (\%) & 0.4 \\
\hline Ash (\%) & 81.5 \\
\hline Ca (\%) (mg) & 220 \\
\hline Fe (mg) & 1 \\
\hline Mg (mg) & 11 \\
\hline P (mg) & 79 \\
\hline K (mg) & 212 \\
\hline Zn (mg) & 1 \\
\hline
\end{tabular}

Table (2): Chemical analysis of olive oil.

\begin{tabular}{|c|c|c|c|c|c|c|c|c|}
\hline Constituent & $\begin{array}{c}\text { Tri }- \\
\text { cycloglycerol I } \\
\boldsymbol{\%}\end{array}$ & $\begin{array}{c}\text { Palmitic } \\
\boldsymbol{\%}\end{array}$ & $\begin{array}{c}\text { Palmitoleic } \\
\boldsymbol{\%}\end{array}$ & $\begin{array}{c}\text { Stearic } \\
\boldsymbol{\%}\end{array}$ & $\begin{array}{c}\text { Oleic } \\
\boldsymbol{\%}\end{array}$ & Linoleic & Linolenic & Arachidic \\
\hline Values & 95 & 17.6 & 2.4 & 54.3 & 22.4 & 22.4 & 1 & 0.06 \\
\hline
\end{tabular}

Table (3): Chemical analysis of jasmine oil.

\begin{tabular}{|c|c|c|c|c|c|c|c|c|}
\hline Constituent & $\begin{array}{c}\text { Benzyl } \\
\text { acetate } \\
\boldsymbol{\%}\end{array}$ & $\begin{array}{c}\text { Benzyl } \\
\text { benzoate } \\
\boldsymbol{\%}\end{array}$ & $\begin{array}{c}\text { Cis- } \\
\text { jasmine } \\
\mathbf{\%}\end{array}$ & $\begin{array}{c}\text { Phytol } \\
\boldsymbol{\%}\end{array}$ & $\begin{array}{c}\text { Methyl } \\
\text { anthranilate }\end{array}$ & $\begin{array}{c}\text { Linalool } \\
\boldsymbol{\%}\end{array}$ & $\begin{array}{c}\text { Geraniol } \\
\boldsymbol{\%}\end{array}$ & $\begin{array}{c}\text { Indol } \\
\boldsymbol{\%}\end{array}$ \\
\hline Values & $25-30$ & $17-20$ & $7-10$ & $7-13$ & $5-7$ & $3-5$ & $3-5$ & 1 \\
\hline
\end{tabular}

Climatic conditions: Average monthly temperature $\left({ }^{\circ} \mathrm{C}\right)$ and relative humidity $(\%)$ under Sohag Governorate conditions are presented in Table (4). In both seasons of the study, the following measurements were determined:

\subsection{Morphological characteristics}

\subsubsection{Date of bud burst and its percentage}

Date of bud burst was recorded. At the beginning of bud burst, the numbers of buds were counted to calculate the percentage of bud burst according to the following equation:

Bud burst $\%=$ Number of open buds/shoot

Total number of buds/shoot

2. 1.2. Vegetative growth parameters

The following measurements were taken

- Average shoot length $(\mathrm{cm})$.

- Average shoot thickness (cm).

- Average number of shoots / tree.

- Number of leaves per shoot.

- Internodes length $(\mathrm{cm})$. 
Table (4): Night time, day time and relative humidity for Sohag Governorate during 2012 to 2014 seasons.

\begin{tabular}{|c|c|c|c|c|c|c|}
\hline \multirow{2}{*}{ Month } & \multicolumn{3}{|c|}{$\mathbf{2 0 1 2 / 2 0 1 3}$} & \multicolumn{3}{|c|}{$\mathbf{2 0 1 3 / 2 0 1 4}$} \\
\cline { 2 - 7 } & $\begin{array}{c}\text { Night time } \\
\left({ }^{\circ} \mathbf{C}\right)\end{array}$ & $\begin{array}{c}\text { Day time } \\
\left({ }^{\circ} \mathbf{C}\right)\end{array}$ & $\begin{array}{c}\text { Relative } \\
\text { humidity }(\boldsymbol{\%})\end{array}$ & $\begin{array}{c}\text { Night time } \\
\left({ }^{\circ} \mathbf{C}\right)\end{array}$ & $\begin{array}{c}\text { Day time } \\
\left({ }^{\circ} \mathbf{C}\right)\end{array}$ & $\begin{array}{c}\text { Relative } \\
\text { humidity }(\boldsymbol{\%})\end{array}$ \\
\hline Oct. & 19.87 & 25.80 & 49.67 & 24.10 & 29.90 & 44.33 \\
\hline Nov. & 13.33 & 18.37 & 56.33 & 17.77 & 23.60 & 57.67 \\
\hline Dec. & 10.33 & 15.23 & 50.00 & 12.50 & 18.03 & 53.33 \\
\hline Jan. & 9.60 & 13.04 & 53.50 & 10.71 & 15.24 & 63.67 \\
\hline Feb. & 11.80 & 16.50 & 48.70 & 13.33 & 18.67 & 47.67 \\
\hline Mar. & 13.40 & 19.20 & 48.00 & 14.62 & 20.70 & 43.00 \\
\hline April & 19.03 & 25.20 & 34.33 & 20.70 & 27.30 & 32.00 \\
\hline May & 23.40 & 29.43 & 33.00 & 24.70 & 30.90 & 38.70 \\
\hline June & 26.40 & 31.80 & 35.33 & 28.30 & 35.60 & 34.71 \\
\hline July & 27.90 & 33.73 & 36.33 & 28.60 & 32.10 & 39.00 \\
\hline Aug. & 27.23 & 32.53 & 38.00 & 29.90 & 33.40 & 37.30 \\
\hline Sep. & 25.00 & 30.30 & 43.00 & 27.60 & 30.00 & 39.00 \\
\hline
\end{tabular}

\subsection{Fruiting and yield of main crop}

- The number of fruits per shoot was counted and calculated per tree.

- Total number of immature fruits per tree was counted and calculate its percentage to the total number of fruits per tree.

- Date of commencement of harvest was calculated as the length of the productive period from the beginning and the end of harvesting.

- Total yield (main crop) per tree $(\mathrm{Kg})$ : fruits were harvested when its skin color was brown to purple. Yield was calculated as (the total number of ripe fruits/tree $\mathrm{X}$ their weight).

\subsection{Physical characteristics of fruits}

In both studied seasons, samples from the mature fig fruits of each treatment were taken to determine the physical properties of fig fruits as follow:

- Average fruit length $(\mathrm{cm})$.

- Average fruit diameter $(\mathrm{cm})$.

- Average fruit weight (gm).

- Fruit volume $\left(\mathrm{cm}^{3}\right)$.

\subsection{Chemical characteristics of fruits}

- Total sugars (\%) content in fresh fruits were determined by phenol sulfuric method according to (Dubois et al., 1956).

- Total soluble solids \% (TSS) was determined using a hand refractometer

according to A.O.A.C. (2000).

- Total acidity (\%) was estimated in fruit as percentage of tartaric acid according to A.O.A.C. (2000). TSS/acidity was calculated.
- Vitamin C (as mg/100 ml juice) was determined as described in A.O.A.C. (2000).

\subsection{Economic evaluation}

Economics feasibility/Feddan of the treatments with garlic oil, olive oil, jasmine oil and Hydrogen cynamides were calculated according to Heady and Dillon (1961) as follows:

- Total cost of spraying garlic oil, olive oil jasmine oil and Hydrogen cynamide /Feddan $=$ the price litter $\times$ number of trees $/$ Feddan $\times$ amount of spraying/tree

- Total gross income $=$ total yield $(\mathrm{kg}) /$ Feddan $\times$ total price

- Fixed cost of agriculture practices $=($ mineral fertilization, pruning, labor, pesticides and others).

- Gross margin= total gross income-total cost.

\subsection{Statistical analysis}

The present data was subjected to analysis of variance (ANOVA) according to (Snedecor and Cochran, 1980). Differences between means were compared by Duncan's multiple range tests (SAS, 1994).

\section{RESULTS AND DISSUSSION}

\subsection{Date of bud burst and its percentage}

Data summarized in Table (5) revealed clearly that, spraying Sultani fig trees with most of the rest-breaking agent hastened the beginning of bud burst and significantly improved the percentage of bud burst during two studied seasons comparing with the control. Using olive oil combined with hydrogen cynamide resulted in earliness of bud emergence 
Table (5): Effect of spraying some natural oils and hydrogen cynamide on the date of bud burst and it's percentage of Sultani fig trees during 2013 and 2014 seasons.

\begin{tabular}{|l|c|c|c|c|}
\hline \multirow{2}{*}{ Treatments } & \multicolumn{2}{|c|}{ Date of bud burst } & \multicolumn{2}{c|}{ Bud burst \% } \\
\cline { 2 - 5 } Control & $\mathbf{2 0 1 3}$ & $\mathbf{2 0 1 4}$ & $\mathbf{2 0 1 3}$ & $\mathbf{2 0 1 4}$ \\
\hline Hydrogen cynamide 1.5\% & $30 / 3$ & $2 / 4$ & $64.58 \mathrm{~d}$ & $61.36 \mathrm{f}$ \\
\hline Garlic oil 3\% & $9 / 3$ & $8 / 3$ & $85.13 \mathrm{bc}$ & $83.41 \mathrm{de}$ \\
\hline Olive oil 3\% & $11 / 3$ & $9 / 3$ & $82.98 \mathrm{c}$ & $81.76 \mathrm{e}$ \\
\hline Jasmine oil 0.3\% & $8 / 3$ & $9 / 3$ & $86.36 \mathrm{a}-\mathrm{c}$ & $86.61 \mathrm{~b}$ \\
\hline Garlic oil 3\%+ 1.5\% Hydrogen cynamide & $9 / 3$ & $11 / 3$ & $88.69 \mathrm{a}-\mathrm{c}$ & $86.07 \mathrm{bc}$ \\
\hline Olive oil 3\%+1.5\% Hydrogen cynamide & $3 / 3$ & $6 / 3$ & $85.80 \mathrm{a}-\mathrm{c}$ & $84.59 \mathrm{~cd}$ \\
\hline Jasmin oil 0.3\%+ 1.5\% Hydrogen cynamide & $5 / 3$ & $6 / 3$ & $91.56 \mathrm{a}$ & $90.11 \mathrm{a}$ \\
\hline
\end{tabular}

Values have the same letter in the same column are not significantly different at 5\% level using Duncan's Multiple Range Test

date by about 27 and 29 days in both seasons, respectively. Moreover, the highest significant bud burst \% was noticed by olive oil combined with hydrogen cynamide compared only with the three treatments of garlic oil, hydrogen cynamide and the control, while, no significant differences occurred between olive oil combined with hydrogen cynamide and the rest of the treatments in the first seasons. Both treatments of olive oil and jasmine oil combined with hydrogen cynamide gave the highest significant percentage of bud burst (90.11 \& $89.35 \%$, respectively) in 2014 season. According to Owino et al. (2006), olive oil produces ethylene that enhances growth and induces flowering. Similarly, sabry et al. (2011) stated that, the increment of the bud burst (\%) by the application of Jasmine oil may be due to playing the same role of hydrogen cynamide. Earliness in budburst with hydrogen cynamide applications may be due to its role in increasing the rate of respiration, measured as $\mathrm{CO}_{2}$ production and in reducing catalase activity as mentioned by Makta, (2013).

\subsection{Vegetative growth}

With regards to the presented results in Table (6), data clearly show that the treatments of oils combined with hydrogen cynamide significantly stimulated most of the vegetative growth of Sultani fig trees in both seasons. Most of the examined treatments had a positive impact on the shoot length. The highest impact was due to spraying trees with olive oil + hydrogen cynamide in the first season. While, in the second season all hydrogen cynamide, jasmine oil and the combination between olive oil and hydrogen cynamide showed the best results. The control trees showed the least shoot length in both seasons. Moreover, there were no significant differences between all treated and un-treated trees in the thickness of branches in both seasons. Also, the data presented in Table (6) showed that olive oil combined with hydrogen cynamide showed a significant increase in the average number of shoots/tree compared with other treatments in the first season. While, in the second season only olive oil with hydrogen cynamide treatment gave the highest significant no. of shoots compared by the control. Meanwhile, the maximum values of the average number of leaves per shoot of fig trees was attained by the trees sprayed with olive oil alone or combined with hydrogen cynamide especially in the first season. On the other hand, in the second season, the significant difference occured only between olive oil with hydrogen cynamide and the two treatments jasmine oil and the control. The minimum records for internodes length observed by spraying with olive oil at $3 \%$ in the first season. While in the second season no significant differences were observed between the applied treatments and the control. The improvements of vegetative growth of Sultani fig trees as a result of spraying trees with garlic, olive and jasmine oil combined with hydrogen cynamide, may be related to the interaction role between oils and hydrogen cynamide for releasing the lateral buds from the apical dominance or reducing the effect of apical dominance in addition to its direct effect on releasing the dormancy exhibited by lateral buds. These results are in line with Stino \& El- 
Table (6): Effect of spraying some natural oils and hydrogen cynamide on some vegetative growth parameters of Sultani fig trees during 2013 and 2014 seasons.

\begin{tabular}{|c|c|c|c|c|c|c|c|c|c|c|}
\hline \multirow[t]{2}{*}{ Treatments } & \multicolumn{2}{|c|}{$\begin{array}{l}\text { Shoot length } \\
(\mathrm{cm})\end{array}$} & \multicolumn{2}{|c|}{\begin{tabular}{|c|} 
Shoot \\
thickness $(\mathrm{cm})$
\end{tabular}} & \multicolumn{2}{|c|}{ No. of shoots } & \multicolumn{2}{|c|}{$\begin{array}{l}\text { No. of leaves/ } \\
\text { shoot }\end{array}$} & \multicolumn{2}{|c|}{$\begin{array}{l}\text { Internode } \\
\text { length }(\mathrm{cm})\end{array}$} \\
\hline & 2013 & 2014 & 2013 & 2014 & 2013 & 2014 & 2013 & 2014 & 2013 & 2014 \\
\hline Control & 82.91 & 83.66 & 2.64 & 2.60 & 36.91 & 36.19 & 14.00 & 15.00 & 5.92 & 5.57 \\
\hline Controt & $\mathrm{e}$ & $\mathrm{d}$ & $\mathrm{a}$ & $\mathrm{a}$ & $\mathrm{e}$ & $\mathrm{b}$ & $\mathrm{d}$ & $\mathrm{c}$ & $\mathrm{a}$ & $\mathrm{a}$ \\
\hline Hydrogen & 86.70 & 92.58 & 2.40 & 2.33 & 42.03 & 37.20 & 16.50 & 17.42 & 5.25 & 5.31 \\
\hline & c & $\mathrm{a}$ & $\mathrm{a}$ & $\mathrm{a}$ & $\mathrm{c}$ & $a b$ & & $\mathrm{a}-\mathrm{c}$ & $\mathrm{a}-\mathrm{c}$ & $\mathrm{a}$ \\
\hline Garlic oil 3\% & $\begin{array}{c}86.48 \\
\mathrm{c}\end{array}$ & $\begin{array}{c}90.15 \\
\mathrm{~b}\end{array}$ & $\begin{array}{c}2.44 \\
\mathrm{a}\end{array}$ & $\begin{array}{c}2.40 \\
\mathrm{a}\end{array}$ & $\begin{array}{c}42.98 \\
\mathrm{c}\end{array}$ & $\begin{array}{c}38.91 \\
\mathrm{ab}\end{array}$ & $\begin{array}{c}17.00 \\
\mathrm{bc}\end{array}$ & $\begin{array}{c}18.50 \\
\mathrm{ab}\end{array}$ & $\begin{array}{c}5.08 \\
a-c\end{array}$ & $\begin{array}{c}4.87 \\
\mathrm{a}\end{array}$ \\
\hline Olive oil 3\% & $\begin{array}{c}86.50 \\
\mathrm{c}\end{array}$ & $\begin{array}{c}86.37 \\
c\end{array}$ & $\begin{array}{c}2.50 \\
\mathrm{a}\end{array}$ & $\begin{array}{c}2.57 \\
\mathrm{a}\end{array}$ & $\begin{array}{c}42.98 \\
\mathrm{c}\end{array}$ & $\begin{array}{c}40.60 \\
\mathrm{ab}\end{array}$ & $\begin{array}{c}19.92 \\
\mathrm{a}\end{array}$ & $\begin{array}{c}19.00 \\
\mathrm{ab}\end{array}$ & $\begin{array}{c}4.34 \\
\mathrm{c}\end{array}$ & $\begin{array}{c}4.54 \\
\mathrm{a}\end{array}$ \\
\hline Jasmine oil $0.3 \%$ & $\begin{array}{c}91.33 \\
\mathrm{~b}\end{array}$ & $\begin{array}{c}92.28 \\
\mathrm{a}\end{array}$ & $\begin{array}{c}2.45 \\
\mathrm{a}\end{array}$ & $\begin{array}{c}2.50 \\
\mathrm{a}\end{array}$ & $\begin{array}{c}38.66 \\
\mathrm{~d}\end{array}$ & $\begin{array}{c}40.58 \\
\mathrm{ab}\end{array}$ & $\begin{array}{c}16.11 \\
\mathrm{c}\end{array}$ & $\begin{array}{c}17.03 \\
\text { bc }\end{array}$ & $\begin{array}{c}5.66 \\
a b\end{array}$ & $\begin{array}{c}5.41 \\
\mathrm{a}\end{array}$ \\
\hline $\begin{array}{l}\text { Garlic oil 3\%+ } 1.5 \% \\
\text { Hydrogen cynamide }\end{array}$ & $\begin{array}{c}84.87 \\
d\end{array}$ & $\begin{array}{c}88.62 \\
b\end{array}$ & $\begin{array}{c}2.23 \\
\mathrm{a}\end{array}$ & $\begin{array}{c}2.20 \\
\mathrm{a}\end{array}$ & $\begin{array}{c}45.69 \\
b\end{array}$ & $\begin{array}{c}40.71 \\
\mathrm{ab}\end{array}$ & $\begin{array}{c}16.76 \\
\mathrm{bc}\end{array}$ & $\begin{array}{c}17.41 \\
\text { a-c }\end{array}$ & $\begin{array}{c}5.06 \\
a-c\end{array}$ & $\begin{array}{c}5.09 \\
\mathrm{a}\end{array}$ \\
\hline $\begin{array}{l}\text { Olive oil 3\%+ } 1.5 \% \\
\text { Hydrogen cynamide }\end{array}$ & $\begin{array}{c}93.67 \\
\mathrm{a}\end{array}$ & $\begin{array}{c}93.13 \\
\mathrm{a}\end{array}$ & $\begin{array}{c}2.33 \\
\mathrm{a}\end{array}$ & $\begin{array}{c}2.27 \\
\mathrm{a}\end{array}$ & $\begin{array}{c}49.14 \\
\mathrm{a}\end{array}$ & $\begin{array}{c}42.85 \\
\mathrm{a}\end{array}$ & $\begin{array}{c}20.00 \\
\mathrm{a}\end{array}$ & $\begin{array}{c}20.69 \\
\mathrm{a}\end{array}$ & $\begin{array}{c}4.68 \\
\mathrm{bc}\end{array}$ & $\begin{array}{c}4.50 \\
\mathrm{a}\end{array}$ \\
\hline $\begin{array}{l}\text { Jasmin oil } 0.3 \%+1.5 \% \\
\text { Hydrogen cynamide }\end{array}$ & $\begin{array}{l}86.24 \\
\text { cd }\end{array}$ & $\begin{array}{c}90.15 \\
b\end{array}$ & $\begin{array}{c}2.17 \\
\mathrm{a}\end{array}$ & $\begin{array}{c}2.20 \\
\mathrm{a}\end{array}$ & $\begin{array}{c}42.44 \\
\mathrm{c}\end{array}$ & $\begin{array}{c}39.63 \\
a b\end{array}$ & $\begin{array}{c}17.75 \\
b\end{array}$ & $\begin{array}{c}18.80 \\
\mathrm{ab}\end{array}$ & $\begin{array}{c}4.85 \\
a-c\end{array}$ & $\begin{array}{c}5.07 \\
\mathrm{a}\end{array}$ \\
\hline
\end{tabular}

Values have the same letter in the same column are not significantly different at $5 \%$ level using Duncan's Multiple Range Test

Fakarani (1995) and Sarita et al., (2015) on Fig trees and, Sabry et al., (2011) on grapevine who found that, jasmine oil at different concentrations plays the same role of hydrogen cynamide. For the role of garlic oil in enhancing vegetative growth may be due to the active substance in garlic diallyi di- and tri- sulfides which was the most effective in promoting vegetative growth according to Mostafa \& Mohamed, 2014. Spraying olive oil has brought about various responses, including growth, flower induction and accelerated fruit ripening (Owino et al., 2006).

\subsection{Fruiting and yield}

As shown in the results presented in Table (7), the highest values of the number of fruits/ shoot was associated with the application of the olive oil alone in the first season and combined with hydrogen cynamide in the second season. As regards the number of fruits/tree, the present results showed that olive oil combined with hydrogen cynamide produced the highest number of fruits/tree comparing with other treatments and the control in both studied seasons. Moreover, the highest number of immature fruits and immature fruits $\%$ were obtained by the control treatment. While, the lowest number of immature fruits was achieved by the trees sprayed by jasmine oil and olive oil in the $1^{\text {st }}$ season and $2^{\text {nd }}$ season, respectively.

The lowest percentage of immature fruits was bserved with olive oil solely or combine with hydrogen cynamide in both seasons. All breaking dormancy treatments significantly increased the yield compared to the un-sprayed control in both seasons. A combination of olive oil and hydrogen cynamide was the most effective compared to the other treatments inducing the weight yield $(22.58$ and $22.64 \mathrm{~kg} /$ tree) in 2013 and 2014 season respectively. These results agree with (Owino et al. (2006) . Abd El-Razek et al. (2011) also demonstrated that, olive oil treatment was more effective in accelerating maturation of fruit as compared to vegetable oils. In addition, Sabry et al. (2011) and Zaghloul et al. (2011) reported that spraying trees with jasmine oil increased the number of fruit/tree. Simillary, Mostafa and Mohamed, (2014) indicated that spraying apple trees with garlic extract increased the number of fruits. The positive action of hydrogen cynamide on breaking dormancy and fruiting is mainly due to its effect in burning bud scales, reducing ABA, reducing catalase, and oxidized glutathione and thus increasing the percentage of fruiting buds burst which leads to an increase in the yield (Makta, 2013). 
Table (7): Effect of spraying some natural oils and hydrogen cynamide on the number of fruits/shoot, the number of fruits/tree, the number of immature fruit, yield/tree and immature fruits percentage of Sultani fig trees during 2013 and 2014 seasons.

\begin{tabular}{|c|c|c|c|c|c|c|c|c|c|c|}
\hline \multirow[t]{2}{*}{ Treatments } & \multicolumn{2}{|c|}{$\begin{array}{c}\text { No. of } \\
\text { fruits/shoot }\end{array}$} & \multicolumn{2}{|c|}{$\begin{array}{l}\text { No. of } \\
\text { fruits/tree }\end{array}$} & \multicolumn{2}{|c|}{$\begin{array}{l}\text { Number of } \\
\text { immature } \\
\text { fruits/tree }\end{array}$} & \multicolumn{2}{|c|}{$\begin{array}{c}\text { Yield } \\
\text { Kg/tree }\end{array}$} & \multicolumn{2}{|c|}{$\begin{array}{l}\text { Immature } \\
\text { fruit } \%\end{array}$} \\
\hline & 2013 & 2014 & 2013 & 2014 & 2013 & 2014 & 2013 & 2014 & 2013 & 2014 \\
\hline \multirow{2}{*}{ Control } & 13.34 & 13.79 & 492.38 & 499.06 & 120.96 & 113.49 & 14.38 & 14.84 & 24.54 & 22.74 \\
\hline & $\mathrm{b}$ & $\mathrm{b}$ & $\mathrm{h}$ & $\mathrm{e}$ & $\mathrm{a}$ & $\mathrm{a}$ & $\mathrm{d}$ & $\mathrm{f}$ & $\mathrm{a}$ & $\mathrm{a}$ \\
\hline \multirow{2}{*}{ Hydrogen cynamide $1.5 \%$} & 13.33 & 14.00 & 560.26 & 520.80 & 110.00 & 99.50 & 16.49 & 16.83 & 19.62 & 19.11 \\
\hline & $\mathrm{b}$ & $\mathrm{b}$ & $\mathrm{f}$ & $\mathrm{e}$ & $\mathrm{d}$ & $\mathrm{e}$ & $\mathrm{c}$ & $\mathrm{e}$ & $\mathrm{b}$ & $\mathrm{b}$ \\
\hline \multirow{2}{*}{ Garlic oil 3\% } & 13.99 & 14.21 & 601.29 & 552.91 & 119.16 & 102.89 & 17.56 & 17.67 & 19.85 & 18.61 \\
\hline & $\mathrm{b}$ & $\mathrm{ab}$ & $\mathrm{d}$ & $\mathrm{d}$ & $\mathrm{b}$ & $\mathrm{d}$ & $\mathrm{c}$ & $\mathrm{cd}$ & $\mathrm{b}$ & $\mathrm{b}$ \\
\hline \multirow{2}{*}{ Olive oil 3\% } & 15.33 & 13.64 & 667.48 & 553.78 & 101.32 & 85.16 & 20.68 & 18.04 & 15.18 & 15.38 \\
\hline & $\mathrm{a}$ & $\mathrm{b}$ & $\mathrm{b}$ & $\mathrm{d}$ & $\mathrm{f}$ & $\mathrm{f}$ & $a b$ & $\mathrm{~cd}$ & $\mathrm{e}$ & $\mathrm{c}$ \\
\hline \multirow{2}{*}{ Jasmine oil $0.3 \%$} & 13.50 & 13.68 & 521.91 & 555.13 & 84.24 & 104.23 & 17.28 & 17.36 & 16.14 & 18.77 \\
\hline & $\mathrm{b}$ & $\mathrm{b}$ & $\mathrm{g}$ & $\mathrm{d}$ & $\mathrm{g}$ & $\mathrm{d}$ & $\mathrm{c}$ & de & de & $\mathrm{b}$ \\
\hline \multirow{2}{*}{$\begin{array}{l}\text { Garlic oil 3\%+1.5\% } \\
\text { Hydrogen cynamide }\end{array}$} & 13.86 & 14.53 & 633.26 & 584.19 & 118.16 & 110.29 & 19.72 & 18.86 & 18.66 & 18.88 \\
\hline & $\mathrm{b}$ & $a b$ & $\mathrm{c}$ & $\mathrm{b}$ & $\mathrm{c}$ & $\mathrm{b}$ & $\mathrm{b}$ & $\mathrm{bc}$ & $\mathrm{bc}$ & b \\
\hline \multirow{2}{*}{$\begin{array}{l}\text { Olive oil } 3 \%+1.5 \% \\
\text { Hydrogen cynamide }\end{array}$} & 14.08 & 15.50 & 691.89 & 664.18 & 105.37 & 105.07 & 22.58 & 22.64 & 15.23 & 15.82 \\
\hline & $a b$ & $\mathrm{a}$ & $\mathrm{a}$ & $\mathrm{a}$ & $\mathrm{e}$ & $\mathrm{c}$ & $\mathrm{a}$ & $\mathrm{a}$ & $\mathrm{e}$ & $\mathrm{c}$ \\
\hline \multirow{2}{*}{$\begin{array}{l}\text { Jasmin oil } 0.3 \%+1.5 \% \\
\text { Hydrogen cynamide }\end{array}$} & 13.80 & 14.21 & 585.67 & 563.14 & 100.65 & 94.89 & 21.14 & 19.98 & 17.19 & 16.85 \\
\hline & $\mathrm{b}$ & $a b$ & $\mathrm{e}$ & $\mathrm{c}$ & $\mathrm{f}$ & $\mathrm{e}$ & $a b$ & $\mathrm{~b}$ & $\mathrm{~cd}$ & $\mathrm{c}$ \\
\hline
\end{tabular}

Values having the same letter in the same column are not significantly different at $5 \%$ level using Duncan's Multiple Range Test

\subsection{Date of commencement of harvest}

Data in Table (8) presented that the combination between olive oil and hydrogen cynamide led to earliness in the beginning of harvesting by about 16 and 12 days and end of harvesting by about 25 and 22 days compared with the control treatment in both seasons, respectively. Similar effects were reported by
Owino et al. (2006) and Abd El-Razek et al. (2011), where the earliness in the beginning and the end of harvesting date may be due to the role of Linolenic acid compounds in olive oil which accelerated fruit growth by inducing ethylene hormone which enhance ripening. In addition, the improving effect of garlic oil may be attributed to the essential role of sulfur

Table (8): Effect of spraying some natural oils and hydrogen cynamide on the date of commencement of harvest of Sultani fig trees during 2013 and 2014 seasons.

\begin{tabular}{|l|c|c|c|c|c|c|}
\hline \multirow{2}{*}{ Treatments } & \multicolumn{2}{c|}{$\begin{array}{c}\text { Beginning } \\
\text { of harvesting }\end{array}$} & \multicolumn{2}{c|}{$\begin{array}{c}\text { End of } \\
\text { harvesting }\end{array}$} & \multicolumn{2}{c|}{$\begin{array}{c}\text { Number of } \\
\text { harvesting days }\end{array}$} \\
\cline { 2 - 7 } & $\mathbf{2 0 1 3}$ & $\mathbf{2 0 1 4}$ & $\mathbf{2 0 1 3}$ & $\mathbf{2 0 1 4}$ & $\mathbf{2 0 1 3}$ & $\mathbf{2 0 1 4}$ \\
\hline Control & $13 / 8$ & $15 / 8$ & $22 / 11$ & $27 / 11$ & 102 & 105 \\
\hline Hydrogen cynamide 1.5\% & $5 / 8$ & $8 / 8$ & $10 / 11$ & $11 / 11$ & 98 & 96 \\
\hline Garlic oil 3\% & $7 / 8$ & $10 / 8$ & $8 / 11$ & $13 / 11$ & 94 & 96 \\
\hline Olive oil 3\% & $3 / 8$ & $6 / 8$ & $5 / 11$ & $10 / 11$ & 94 & 96 \\
\hline Jasmine oil 0.3\% & $7 / 8$ & $10 / 8$ & $10 / 11$ & $13 / 11$ & 95 & 95 \\
\hline Garlic oil 3\%+ 1.5\% Hydrogen cynamide & $3 / 8$ & $8 / 8$ & $5 / 11$ & $13 / 11$ & 94 & 97 \\
\hline Olive oil 3\%+ 1.5\% Hydrogen cynamide & $28 / 7$ & $3 / 8$ & $29 / 10$ & $5 / 11$ & 94 & 94 \\
\hline Jasmin oil 0.3\%+ 1.5\% Hydrogen cynamide & $1 / 8$ & $5 / 8$ & $2 / 11$ & $10 / 11$ & 94 & 97 \\
\hline
\end{tabular}


substances in the synthesis of some amino acids and consequently, formation of growth regulators especially auxin that has a positive action on enhancing growth parameters that affect the harvesting date (Botelho et al., 2007).

\subsection{Physical quality characteristics of fruits}

Data in Table (9) clearly illustrate that trees treated with jasmine oil mixed with Hydrogen cynamide had the significantly highest fruit weight only when compared with hydrogen cynamide, garlic oil and olive oil treatments in the first season. While, in the second season, jasmine oil mixed with hydrogen cynamide had the highest significant fruit weight compared with all treatments. Regarding fruit length, both treatments of olive oil and jasmine oil mixed with hydrogen cynamide recorded the highest significant fruit length in the first season. On the other side, the lowest significant fruit length in the second season observed by the control compared with the rest of the treatments that had no significant differences between each other's. Regarding fruit diameter, no significant differences was observed between all treatments the second season, where the biggest fruit volume was recorded by all three oil treatments (olive, garlic and jasmin) mixed with hydrogen cynamide.

These results agree with Sabry et al. (2011) on grape vine, Barakat et al. (2015) on Valencia orange and Zeinab et al. (2017) on date palm. Moreover, the improvements in the physical quality of fruits as a result of spraying trees with garlic oils may be due to its sulfur containing which is a constituent of the amino acids cysteine and methionine, and hence proteins. These amino acids are precursors of other sulfurcontaining compounds such as coenzymes and gibberline that lead to improving fruit quality. The obtained results are in line with those achieved by Hemat et al. (2014) on Cumin plants, Mostafa and Mohamed (2014) on apple trees and Sarita et al. (2015) on fig trees. The positive effect attained as a result of spraying olive oil, is in agreement with Abd El-Razek et al. (2011) who reported that spraying apple trees with olive oil at mid of January improved fruits physical quality.

Table (9): Effect of spraying some natural oils and hydrogen cynamide on fruit physical properties of Sultani fig trees during 2013 and 2014 seasons.

\begin{tabular}{|c|c|c|c|c|c|c|c|c|}
\hline \multirow[t]{2}{*}{ Treatment } & \multicolumn{2}{|c|}{$\begin{array}{l}\text { Fruit weight } \\
\text { (gm) }\end{array}$} & \multicolumn{2}{|c|}{$\begin{array}{l}\text { Fruit length } \\
\text { (cm) }\end{array}$} & \multicolumn{2}{|c|}{$\begin{array}{l}\text { Fruit diameter } \\
\text { (cm) }\end{array}$} & \multicolumn{2}{|c|}{$\begin{array}{l}\text { Fruit volume } \\
\qquad(\mathrm{cm})^{3}\end{array}$} \\
\hline & 2013 & 2014 & 2013 & 2014 & 2013 & 2014 & 2013 & 2014 \\
\hline Control & $\begin{array}{c}38.70 \\
\mathrm{ab}\end{array}$ & $\begin{array}{c}38.50 \\
\mathrm{~d}\end{array}$ & $\begin{array}{c}3.33 \\
d\end{array}$ & $\begin{array}{c}3.10 \\
b\end{array}$ & $\begin{array}{c}3.70 \\
\mathrm{a}\end{array}$ & $\begin{array}{c}3.47 \\
\mathrm{~d}\end{array}$ & $\begin{array}{c}32.34 \\
\mathrm{~d}\end{array}$ & $\begin{array}{c}34.00 \\
\text { ef }\end{array}$ \\
\hline Hydrogen cynamide $1.5 \%$ & $\begin{array}{c}36.60 \\
b\end{array}$ & $\begin{array}{c}39.97 \\
\text { bc }\end{array}$ & $\begin{array}{c}3.70 \\
\mathrm{bc}\end{array}$ & $\begin{array}{c}3.47 \\
\mathrm{a}\end{array}$ & $\begin{array}{c}3.73 \\
\mathrm{a}\end{array}$ & $\begin{array}{c}3.83 \\
\mathrm{c}\end{array}$ & $\begin{array}{c}33.70 \\
\mathrm{c}\end{array}$ & $\begin{array}{c}38.00 \\
\text { bc }\end{array}$ \\
\hline Garlic oil 3\% & $\begin{array}{c}36.50 \\
b\end{array}$ & $\begin{array}{c}39.27 \\
\mathrm{~cd}\end{array}$ & $\begin{array}{c}3.53 \\
\mathrm{~cd}\end{array}$ & $\begin{array}{c}3.47 \\
\mathrm{a}\end{array}$ & $\begin{array}{c}3.93 \\
\mathrm{a}\end{array}$ & $\begin{array}{c}4.27 \\
\mathrm{~b}\end{array}$ & $\begin{array}{c}32.45 \\
\mathrm{~d}\end{array}$ & $\begin{array}{c}35.66 \\
\text { de }\end{array}$ \\
\hline Olive oil 3\% & $\begin{array}{c}36.53 \\
b\end{array}$ & $\begin{array}{c}38.50 \\
d\end{array}$ & $\begin{array}{c}3.63 \\
b c\end{array}$ & $\begin{array}{c}3.53 \\
\mathrm{a}\end{array}$ & $\begin{array}{c}4.00 \\
\mathrm{a}\end{array}$ & $\begin{array}{c}3.87 \\
\mathrm{c}\end{array}$ & $\begin{array}{c}32.67 \\
\mathrm{~cd}\end{array}$ & $\begin{array}{c}32.67 \\
f\end{array}$ \\
\hline Jasmine oil $0.3 \%$ & $\begin{array}{c}39.50 \\
\mathrm{ab}\end{array}$ & $\begin{array}{c}38.50 \\
\mathrm{~d}\end{array}$ & $\begin{array}{c}3.81 \\
\mathrm{~b}\end{array}$ & $\begin{array}{c}3.80 \\
\mathrm{a}\end{array}$ & $\begin{array}{c}3.94 \\
\text { a }\end{array}$ & $\begin{array}{c}4.21 \\
\mathrm{~b}\end{array}$ & $35.33 \mathrm{~b}$ & $\begin{array}{c}36.33 \\
\mathrm{~cd}\end{array}$ \\
\hline $\begin{array}{l}\text { Garlic oil 3\%+ } 1.5 \% \\
\text { Hydrogen cynamide }\end{array}$ & $\begin{array}{c}38.30 \\
a b\end{array}$ & $\begin{array}{c}39.80 \\
\mathrm{bc}\end{array}$ & $\begin{array}{c}3.80 \\
\mathrm{~b}\end{array}$ & $\begin{array}{c}3.73 \\
\mathrm{a}\end{array}$ & $\begin{array}{c}4.20 \\
\mathrm{a}\end{array}$ & $\begin{array}{c}4.17 \\
b\end{array}$ & $35.27 \mathrm{~b}$ & $\begin{array}{c}39.00 \\
\mathrm{ab}\end{array}$ \\
\hline $\begin{array}{l}\text { Olive oil } 3 \%+1.5 \% \\
\text { Hydrogen cynamide }\end{array}$ & $\begin{array}{c}38.50 \\
\mathrm{ab}\end{array}$ & $\begin{array}{l}40.50 \\
\mathrm{~b}\end{array}$ & $\begin{array}{c}4.07 \\
\mathrm{a}\end{array}$ & $\begin{array}{c}3.87 \\
\mathrm{a}\end{array}$ & $\begin{array}{c}4.13 \\
\mathrm{a}\end{array}$ & $\begin{array}{c}3.83 \\
\mathrm{c}\end{array}$ & $35.61 \mathrm{~b}$ & $\begin{array}{c}40.00 \\
\mathrm{a}\end{array}$ \\
\hline $\begin{array}{l}\text { Jasmin oil } 0.3 \%+1.5 \% \\
\text { Hydrogen cynamide }\end{array}$ & $\begin{array}{c}43.60 \\
\mathrm{a}\end{array}$ & $\begin{array}{c}42.67 \\
\mathrm{a}\end{array}$ & $\begin{array}{c}4.13 \\
\mathrm{a}\end{array}$ & $\begin{array}{c}4.27 \\
\mathrm{a}\end{array}$ & $\begin{array}{c}4.23 \\
\mathrm{a}\end{array}$ & $\begin{array}{c}4.67 \\
\mathrm{a}\end{array}$ & $\begin{array}{c}39.11 \\
\mathrm{a}\end{array}$ & $\begin{array}{c}40.33 \\
\mathrm{a}\end{array}$ \\
\hline
\end{tabular}

Values have the same letter in the same column are not significantly different at $5 \%$ level using Duncan's Multiple Range Test.

in the first season but in the second season, the highest significant fruit diameter was marked only by jasmine oil mixed with hydrogen cynamide. The previous treatment also gave the biggest fruit volume in the first season while, in

\subsection{Chemical composition of fruits}

The computed results in Table (10) point out that hydrogen cynamide, olive oil and jasmin oil alone or combined with hydrogen cynamide gave significantly the highest TSS compared 
Table (10): Effect of spraying some natural oils and hydrogen cynamide on fruit chemical properties of Sultani fig trees during 2013 and 2014 seasons.

\begin{tabular}{|c|c|c|c|c|c|c|c|c|c|c|}
\hline \multirow[t]{2}{*}{ Treatment } & \multicolumn{2}{|c|}{$\begin{array}{c}\text { TSS } \\
\%\end{array}$} & \multicolumn{2}{|c|}{$\begin{array}{c}\text { Acidity } \\
\%\end{array}$} & \multicolumn{2}{|c|}{ TSS/acidity } & \multicolumn{2}{|c|}{ Total sugars \% } & \multicolumn{2}{|c|}{ VC mg/100g } \\
\hline & 2013 & 2014 & 2013 & 2014 & 2013 & 2014 & 2013 & 2014 & 2013 & 2014 \\
\hline Control & 14.75 & 15.50 & 0.339 & 0.342 & 43.51 & 45.32 & 12.50 & 13.25 & 9.84 & 9.86 \\
\hline $\begin{array}{l}\text { Hydrogen } \\
\text { cynamide } 1.5 \%\end{array}$ & $\begin{array}{c}16.84 \\
\mathrm{a}\end{array}$ & $\begin{array}{c}16.95 \\
\text { ab }\end{array}$ & $\begin{array}{c}0.315 \\
\mathrm{a}\end{array}$ & $\begin{array}{c}0.319 \\
\mathrm{c}\end{array}$ & $\begin{array}{c}53.46 \\
\mathrm{~d}\end{array}$ & $\begin{array}{c}53.13 \\
a-c\end{array}$ & $\begin{array}{c}15.15 \\
\mathrm{ab}\end{array}$ & $\begin{array}{c}15.50 \\
\mathrm{a}\end{array}$ & $\begin{array}{c}9.85 \\
\mathrm{a}\end{array}$ & $\begin{array}{c}9.85 \\
\mathrm{a}\end{array}$ \\
\hline Garlic oil 3\% & $\begin{array}{c}15.20 \\
b c\end{array}$ & $\begin{array}{c}16.00 \\
\mathrm{ab}\end{array}$ & $\begin{array}{c}0.333 \\
\mathrm{a}\end{array}$ & $\begin{array}{c}0.330 \\
b\end{array}$ & $\begin{array}{c}45.65 \\
\mathrm{f}\end{array}$ & $\begin{array}{c}48.48 \\
\text { bc }\end{array}$ & $\begin{array}{c}14.35 \\
\mathrm{~b}\end{array}$ & $\begin{array}{c}15.29 \\
\mathrm{a}\end{array}$ & $\begin{array}{c}9.66 \\
\mathrm{a}\end{array}$ & $\begin{array}{c}9.64 \\
\mathrm{a}\end{array}$ \\
\hline Olive oil 3\% & $\begin{array}{c}17.55 \\
\mathrm{a}\end{array}$ & $\begin{array}{c}17.32 \\
\mathrm{a}\end{array}$ & $\begin{array}{c}0.290 \\
\mathrm{a}\end{array}$ & $\begin{array}{c}0.299 \\
\mathrm{e}\end{array}$ & $\begin{array}{c}60.52 \\
\mathrm{a}\end{array}$ & $\begin{array}{c}57.93 \\
\mathrm{a}\end{array}$ & $\begin{array}{c}16.35 \\
\mathrm{a}\end{array}$ & $\begin{array}{c}15.73 \\
\mathrm{a}\end{array}$ & $\begin{array}{c}9.75 \\
\mathrm{a}\end{array}$ & $\begin{array}{c}9.73 \\
\mathrm{a}\end{array}$ \\
\hline Jasmine oil 0.3\% & $\begin{array}{c}17.03 \\
\mathrm{a}\end{array}$ & $\begin{array}{c}16.99 \\
\mathrm{ab}\end{array}$ & $\begin{array}{c}0.305 \\
\mathrm{a}\end{array}$ & $\begin{array}{c}0.307 \\
\mathrm{~d}\end{array}$ & $\begin{array}{c}55.84 \\
\mathrm{c}\end{array}$ & $\begin{array}{c}55.34 \\
\mathrm{ab}\end{array}$ & $\begin{array}{c}15.90 \\
\mathrm{a}\end{array}$ & $\begin{array}{c}15.66 \\
\mathrm{a}\end{array}$ & $\begin{array}{c}9.75 \\
\mathrm{a}\end{array}$ & $\begin{array}{c}9.74 \\
\mathrm{a}\end{array}$ \\
\hline & $\begin{array}{c}16.75 \\
\mathrm{ab}\end{array}$ & $\begin{array}{c}16.90 \\
\mathrm{ab}\end{array}$ & $\begin{array}{c}0.327 \\
\mathrm{a}\end{array}$ & $\begin{array}{c}0.330 \\
b\end{array}$ & $\begin{array}{c}51.22 \\
\mathrm{e}\end{array}$ & $\begin{array}{c}51.21 \\
\mathrm{a}-\mathrm{c}\end{array}$ & $\begin{array}{c}15.11 \\
\mathrm{ab}\end{array}$ & $\begin{array}{c}15.95 \\
\mathrm{a}\end{array}$ & $\begin{array}{c}9.71 \\
\mathrm{a}\end{array}$ & $\begin{array}{c}9.75 \\
\mathrm{a}\end{array}$ \\
\hline $\begin{array}{l}\text { Olive oil } 3 \%+1.5 \% \\
\text { Hydrogen cynamide }\end{array}$ & $\begin{array}{c}17.40 \\
\mathrm{a}\end{array}$ & $\begin{array}{c}17.50 \\
\mathrm{a}\end{array}$ & $\begin{array}{c}0.296 \\
\mathrm{a}\end{array}$ & $\begin{array}{c}0.294 \\
\mathrm{e}\end{array}$ & $\begin{array}{c}58.78 \\
\mathrm{~b}\end{array}$ & $\begin{array}{c}59.52 \\
\mathrm{a}\end{array}$ & $\begin{array}{c}15.50 \\
\mathrm{ab}\end{array}$ & $\begin{array}{c}15.77 \\
\mathrm{a}\end{array}$ & $\begin{array}{c}9.97 \\
\mathrm{a}\end{array}$ & $\begin{array}{c}9.91 \\
\mathrm{a}\end{array}$ \\
\hline $\begin{array}{l}\text { Jasmin oil } 0.3 \%+1.5 \% \\
\text { Hydrogen cynamide }\end{array}$ & $\begin{array}{c}17.14 \\
\mathrm{a}\end{array}$ & $\begin{array}{c}17.11 \\
\mathrm{ab}\end{array}$ & $0.310 \mathrm{a}$ & $\begin{array}{c}0.308 \\
\mathrm{~d}\end{array}$ & $\begin{array}{c}55.29 \\
\mathrm{c}\end{array}$ & $\begin{array}{c}55.55 \\
\mathrm{ab}\end{array}$ & $\begin{array}{c}15.95 \\
\mathrm{a}\end{array}$ & $\begin{array}{c}15.75 \\
\mathrm{a}\end{array}$ & $\begin{array}{c}9.93 \\
\mathrm{a}\end{array}$ & $\begin{array}{c}9.95 \\
\mathrm{a}\end{array}$ \\
\hline
\end{tabular}

Values have the same letter in the same column are not significantly different at 5\% level using Duncan's Multiple Range Test.

only with garlic oil and the control in the first season. While, both treatments olive oil solely or mixed with hydrogen cynamide recorded the significantly highest TSS compared with the control in the second seasons. Moreover, there was no significant different between the treatments in the acidity \% in the first season, while the lowest percent of acidity achieved by two treatments olive oil solely or mixed with hydrogen cynamide in the second season. Meanwhile, the highest significant value of TSS/ acidity booked by olive oil $3 \%$ in the $1^{s t}$ season. The olive oil $3 \%$ treatment solely or combined with hydrogen cynamide achieved the highest percentage of TSS/acidity comparing with garlic oil $3 \%$ and control in the $2^{\text {nd }}$ season. Regarding the sugar content $\%$, all treatments recorded the highest sugar content comparing with control in both seasons. In addition, no statistically differences were detected among the treatments in the fruit content of vitamin $\mathrm{C}$ during the two seasons. The above mentioned results are in conformity with the findings by (Jin et al., (2009), sabry et al. (2011) and Barakat et al. (2015). Moreover, Mostafa and Mohamed (2014) disclosed that spraying apple trees in January with garlic extracts and olive oil led to increase the total soluble solids, the total sugars and decrease acidity comparing with the control. Also, the favorable effect of used olive oil may be attributed to the essential role of fatty acids that enhancing formation growth regulators that may be improving the component of fruit (Owino et al., 2006).

\subsection{Economic feasibility/Feddan}

It can be shown from the data presented in Table (11) that all natural oils (garlic, olive, jasmine) gave better net profit than both the hydrogen cynamide and the control. The highest production obtained was due to the treatment of $3 \%$ olive oil $+1.5 \%$ hydrogen cynamide, which resulted also in the highest net profit/Feddan (13263.6 LE) followed by $0.3 \%$ jasmine oil + $1.5 \%$ hydrogen cynamide comparing with other treatments. Untreated trees gave the lowest net profit (7483.5 L.E).

\section{Conclusion}

In the recent years, the popular interest in consuming fresh fig fruits has increased, mainly due to the large presence of bioactive compounds in the fruits. As a result of the rapid growth in the world market, the use of natural products in horticultural practices instead of synthetic chemicals is becoming a main target for many fruit crop producers, because it is environmentally safe. Thus, using natural oils that act as sprouting inducers on earliness in bud break of fruit trees becomes a dominant tool to produce economic fig yield in warm winter regions (Sarita et al., 2015). 
Table (11): Cost and net profit/Feddan of Sultani Fig trees spraying with some natural oils and hydrogen cynamide.

\begin{tabular}{|l|c|c|c|c|c|c|}
\hline \multicolumn{1}{|c|}{ Treatments } & $\begin{array}{c}\text { Yield/ } \\
\text { Feddan } \\
\text { (kg) }\end{array}$ & $\begin{array}{c}\text { Price } \\
\text { (LE) }\end{array}$ & $\begin{array}{c}\text { Price of } \\
\text { Spraying } \\
\text { /Feddan }\end{array}$ & $\begin{array}{c}\text { Fixed cost of } \\
\text { agriculture } \\
\text { /Feddan }\end{array}$ & $\begin{array}{c}\text { Total cost } \\
\text { (LE) }\end{array}$ & $\begin{array}{c}\text { Net profit } \\
\text { (LE) }\end{array}$ \\
\hline Control & 3827.80 & 11483.5 & ---- & 4000 & 4000 & 7483.5 \\
\hline $\begin{array}{l}\text { Hydrogen } \\
\text { cynamide 1.5\% }\end{array}$ & 4364.90 & 13094.7 & 100 & 4100 & 4200 & 8894.7 \\
\hline Garlic oil 3\% & 4615.10 & 13845.4 & 400 & 4100 & 4500 & 9345.4 \\
\hline Olive oil 3\% & 5072.30 & 15216.9 & 200 & 4100 & 4300 & 10916.9 \\
\hline Jasmine oil 0.3\% & 4537.84 & 13613.5 & 300 & 4100 & 4400 & 9213.5 \\
\hline $\begin{array}{l}\text { Garlic oil 3\%+ 1.5\% } \\
\text { Hydrogen cynamide }\end{array}$ & 5053.90 & 15161.9 & 500 & 4200 & 4700 & 10461.9 \\
\hline $\begin{array}{l}\text { Olive oil 3\%+ 1.5\% } \\
\text { Hydrogen cynamide }\end{array}$ & 5921.20 & 17763.6 & 300 & 4200 & 4500 & 13263.6 \\
\hline $\begin{array}{l}\text { Jasmin oil 0.3\%+ 1.5\% } \\
\text { Hydrogen cynamide }\end{array}$ & 5386.70 & 16160.1 & 400 & 4200 & 4600 & 11560.1 \\
\hline
\end{tabular}

Finally, it could be concluded from the present study that spraying 'Sultani' fig trees grown under warm winter with $3 \%$ of olive oil combined with hydrogen cynamide at $1.5 \%$ resulted in improving the productivity, fruit quality and reducing immature fig fruits, thus leading to achieve higher profitability.

\section{REFERENCES}

A.O.A.C., (2000). Association of Official Agricultural Chemists "Official Methods of Analysis". 17 $7^{\text {th }}$ Ed. Benjamin Franklin Station, Washington D.C., U.S.A. 490510.

Abd El-Razek E., Abd El-Migeed M. M. and Abdel-Hamid N. (2011). Effect of spraying garlic extract and olive oil on flowering behavior, yield and fruit quality of Canino apricot trees. Amer. Eurasian J. Agric. \& Environ. Sci., 11: 776-781.

Ahmed M. A. M., Eman A. A. and Abd ElMigeed M. M. M. (2009). Effect of garlic extract and mineral oil spray on flowering, harvesting time, yield and fruit yield and fruit quality of Peach trees C.V. Florida prince. Eastern and Russ. J. Plant Sci. and Biotech., 3: 5357.

Barakat M.R., Abeer T.M. and Azhar A.M. (2015). Effect of some natural oils and salicylic acid on fruit quality of Valencia orange during storage. J. Hort. Sci. Ornament Plants.,7: 66-70.

Botelho R. V., Pavanello A. P., Pires E. J. P.,
Terra M. M. and Müller M.L. (2007). Effects of chilling and garlic extract on bud dormancy release in Cabernet Sauvignon grapevine. Ame. J. of Enol. and Viticult., 58:402-404.

Dubois M., Gilles K. A., Homilton J.K., Robers P.A. and Smith F. (1956). Colorimetric methods for determination of sugar and related substances. Anal. Chem., 28(3):350-458.

El-Bolok T. K. A. (2006). Histophysiological effects of training Sultani Fig cultivar on Wire. Ph.D. Thesis, Faculty of Agriculture, Assiut University, Egypt.

El-Sabrout M. B. (1998). Some physiological and biochemical responses of Flame Seedless grapevines to hydrogen cynamide (Dormex) spray. Alex. J. Agric. Res. Egypt. 43: 167 - 185.

Ewa S., Igorkhmelinskii $\mathrm{H}$. and Marek S. (2015). Analysis of olive oils by Fluorescence spectroscopy: Methods and applications. Faculty of chemistry, Mickiewicz University, Poland.

FAO (2011). FAO. Statistics Division (2013). available at: (http:// faostat. fao.org/ site/339/default.aspx), 20 July 2013.

Feng L. J., Zheng Y. H. and Zahng Y.F. (2003). Jasmonate reducing chilling injury and maintains post-harvest quality in peaches. Agric. Sci. China-CN, 11: 1246-1252.

Fuchigami L. H., Weiser C.J., Kobayashi K., Timmis R. and Gusta L.V. (1982). A degree growth stage (GSO) model and 
cold accumulation in temperate woody plants. 93-116. In: P. Li and A. Sakai (eds.). Plant cold hardiness and freezing stress. Academic, press, New York, USA.

Hartmann T., Mult S., Suter M., Rennenberg H. and Heschbach C. (2000). Leaf agedependent differences in sulfur assimilation and allocation in poplar (Populus ternulaxp Alba) leaves. J. Exp. Botany, plants, 51: 1077-1088.

Heady E. O., and Dillon J. L. (1961). Agricultural Production Functions. Iowa State University Press., Iowa State University Ames, Iowa, U.S.A.

Hemat S., Abd El-Salam A., Dahab A. and Mohamed M.F. (2014). Enhancement of Cumin (Cuminum cyminum L.) productivity using some natural plant extracts. Egypt. J. Hort., 41: 209-219.

Hirai J., Hirata N., Horiuchi H. (1996). Effect of Oleification on hastening the maturity of fig fruits. J. Japanese Hort. Sci., 36: 268-274.

Jin P., Yonghua Z., Shuangshuang T., Huaijin R. and Wang C.Y. (2009). A combination of hot air and methyl jasmonate vapor treatment alleviates chilling injury of peach fruit. Postharvest Biol. and Tech., 52: 24-29.

Kittikorn M. and Kanlayanarat S. (2004). Relationships between jasmonates and chilling injury in mangosteens are affected by spermine. HortSci., 39: 1346-1348.

Lanzotti V. (2006). The analysis of onion and garlic. J. of Chromatography., 1112: 322.

Makta F.W. (2013). The application of cynamide on termination of dormancy in grapevine. J. Plant Growth Regul. 8:301-307.

Mcartney S.J. and Walker J.T.S. (2004). Current situation and future challenges facing the production and marketing of organic fruit in Oceania. Acta Hort., 638: 387396.

Moshe A. F. (2008). The Fig: Botany, Horticulture, and Breeding. Department of Fruit Tree Sciences, Agricultural Research Organization, Volcani Center, Bet Dagan 50250, Israel 1:89

Mostafa M. R. and Mohamed A. S. (2014). Garlic extract as a novel strategy to hasten dormancy release in buds of
Anna apple trees. South Afr. J. Bot., 92: 105-111.

Omri A. (2006). Organic products list. Organic Materials Review Institute (OMRI). Available at http:// www.omri.org Accessed 10 March 2006.

Oukabi A. and Mekaoui A. (2012). Dormancy of fig cultivated under Moroccan conditions. Amer. J. Plant Sci. ,55:473479.

Owino W.O., Manabe Y., Mathooko F.M., Kubo Y. and Inaba A. (2006). Regulatory mechanisms of ethylene biosynthesis in response to various stimuli during maturation and ripening in fig fruit. Plant Physiol. and Biochem., 44:335-342.

Pinto M., Lira V., Ugalde H. and Perez F. (2014). Compounds derived from garlic as bud induction agent in organic farming of table grape. Chilean J. Agric. Res., 68: 94-101.

Sabry G. H., El-Helw H. A. and Abd El-Rahman A. S. (2011). A study on using jasmine oil as a breaking bud dormancy for flame seedless grapevines. Report and Opinion, 3: 48-56.

Sarita L., Tecchio M. A. and Angeli G. M. (2015). Dormancy breaking of the fig tree with hydrogen cyanamide and garlic extract. British J. Appl. Sci. \& Techn. 10, 1-10.

SAS (1994). SAS Statistics program, Version $6.4^{\text {th }}$ Ed. SAA Inst., Cary, NT.

Saure M.C. (1985). Dormancy release in deciduous fruit trees. Hot. Rev. 7: 39300.

Segantini D. M., Leonel S., Ripardo A.C.S. and Auricchio M. G. R. (2011). Use of growth regulators to break dormancy and its influence on budding, flowering and yield in the black mulberry. Brazil. J. Fruticult., 8:275-280.

Settimi L. D., Faraoni F., Richmond M. G. and Calvert G.M. (2005). Update Hydrogen cyanamide-related Ilnesses. Italy, 2002-2004. Morbidity and Mortality Weekly paper .54: 405- 408.

Snedecor G. W. and Cochran W. G. (1980). Statistical Methods. $7^{\text {th }}$ Ed. Iowa State Univ. Press, Ames, Iowa, USA PP. 507.

Souza A. P., Silva A.C., Leonel S. and Escobedo J.F. (2009). Basal temperature and thermal time the fig tree pruned at different times. Brazil., J. Fruticult., 31:314-322. 
Stino R.G. and El- Fakarani E. (1995). Fruiting of Conadria trees affected by type of pruning and hydrogen syanamide application. Egypt J. Hort. 22: 193-211.

Wang L., Jiang W., Ling K. M. Z. and Wang Y. (2003). The production and research of fig (Ficus carjca L.) in China. Acta

Zaghloul A. E., Abd El- Naiem A. E. and Hamdy E. E. (2011). Application of activated jasmine oil on navel orange trees. b-improving storability and shelflife. J. Agric. Res. Kafer El-Sheikh Univ., 37: 370-384.

Zeinab A. Z., Yousef A. R., Abd El-Moneim E. A. and Emad H. E. (2017). Effect of some natural extracts on maintaining quality of Zaghloul date palm fruits during cold storage. Middle East J. Agric., Res., 6: 464-473.

$$
\begin{aligned}
& \text { تاثير الرش بسيناميد الهيدروجين وزيت الثوم وزيت الزيتون وزيت الياسمين }
\end{aligned}
$$

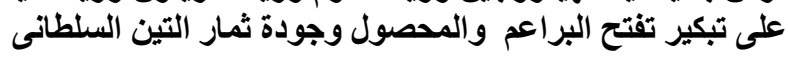

$$
\begin{aligned}
& \text { شيرين عاطف شاهين - احمد صلاح الدين السودة ـ طارق خلف البلك }
\end{aligned}
$$$$
\text { قسم بحوث الزيتون وفاكهة المناطق شبه الجافة ـ معهد بحوث البساتين ـ مركز البحوث الزر اعية ـ الجيزة ـمصر }
$$

اجريت هذة الدراسة خلال موسمى 2013 و2014 على اشجار التين السلطانى المنزرعة بالمزرعة البحثية التابعة لمركز

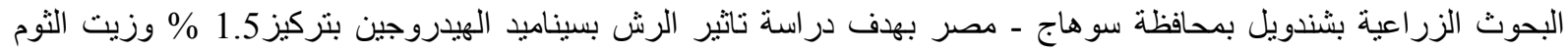

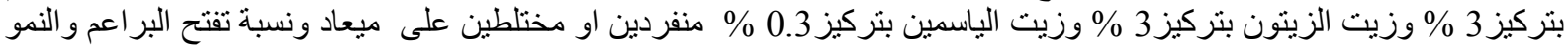

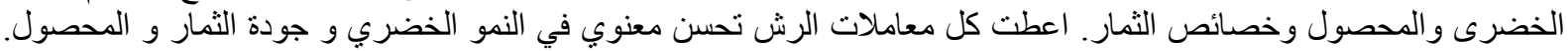

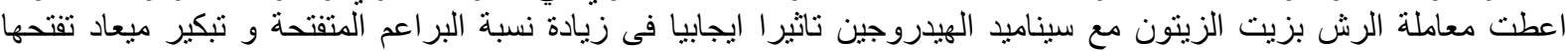

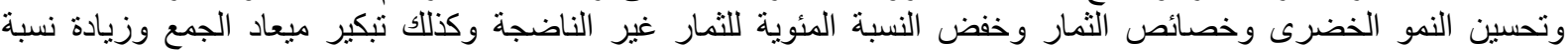

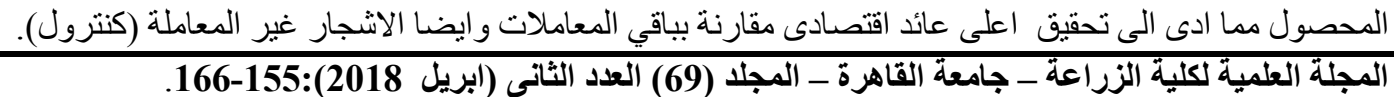

